\title{
TEORI KONSTRUKTIVISME DALAM PEMBELAJARAN
}

\author{
Suparlan \\ STIT Palapa Nusantara Lombok NTB \\ maniahparlan66@gmail.com
}

\begin{abstract}
The task for education is not only limited to diverting the results of science and technology. In addition, the education sector has the duty to instill new values demanded by the development of science and technology in students within the framework of the basic values agreed upon by the Indonesian people. In general, the theory is a number of syntactically integrated proposals (these propositions follow rules that can logically link one proposal to another, and also to the observed data), as well as those used to predict and explain events. observed. Constivism is an active activity, where students develop their own knowledge, look for the meaning of what they are learning, and are a process of completing new concepts and ideas with their existing framework of thinking.
\end{abstract}

Keywords: Theory, Constructivism

\begin{abstract}
Abstrak : Tugas bagi pendidikan tidak hanya terbatas pada mengalihkan hasil-hasil ilmu dan teknologi. Selain itu, bidang pendidikan bertugas pula menanamkan nilainilai baru yang dituntut oleh perkembangan ilmu dan teknologi pada diri anak didik dalam kerangka nilai-nilai dasar yang telah disepakati oleh bangsa Indonesia. Secara umum teori merupakan sejumlah proposal yang terintegrasi secara sintakstik (kumpulan proposisi ini mengikuti aturan-aturan yang dapat menghubungkan secara logis proposal yang satu dengan proposal yang lain, dan juga pada data yang diamati), serta yang digunakan untuk memprediksi dan menjelaskan peristiwa-peristiwa yang diamati. konstuktivisme adalah aktivitas yang aktif, di mana peserta didik membina sendiri pengetahuannya, mencari arti dari apa yang mereka pelajari, dan merupakan proses menyelesaikan konsep dan ide-ide baru dengan kerangka berfikir yang telah ada dimilikinya.
\end{abstract}

Kata kunci : Teori, Konstruktivisme

Islamika : Jurnal Keislaman dan Ilmu Pendidikan

Volume 1, Nomor 2, Juli 2019; 79-88

https:// ejournal.stitpn.ac.id/index.php/islamika 


\section{PENDAHULUAN}

Tugas bagi pendidikan tidak hanya terbatas pada mengalihkan hasil-hasil ilmu dan teknologi. Selain itu, bidang pendidikan bertugas pula menanamkan nilai-nilai baru yang dituntut oleh perkembangan ilmu dan teknologi pada diri anak didik dalam kerangka nilai-nilai dasar yang telah disepakati oleh bangsa Indonesia. ${ }^{1}$

Meningkatkan mutu pendidikan merupakan suatu proses yang harus dilaksanakan secara terus menerus untuk meningkatkan kualitas proses belajar mengajar dan berbagai faktor yang berkaitan dengan itu, dengan arah agar tujuan pendidikan dapat dicapai secara efektif dan lebih efisien. Muara dari peningkatan mutu tidak lain adalah pencapaian tujuan pendidikan, yang diujudkan kemampuan yang utuh pada diri peserta didik. Proses belajar mengajar menempati posisi yang amat penting dan menentukan. Namun, perlu dicatat bahwa proses belajar mengajar merupakan suatu interaksi yang bersifat manusiawi antara pendidik dan peserta didik yang penuh mengandung ketidakpastian. ${ }^{2}$

Upaya mencerdaskan kehidupan bangsa dan mengembangkan kualitas manusia seutuhnya, adalah misi pendidikan yang menjadi tanggung jawab profesional setiap guru. Pengembangan kualitas manusia ini menjadi suatu keharusan, terutama dalam memasuki era globalisasi dewasa ini, agar generasi muda kita menjadi korban dari globalisasi itu sendiri. Pendidikan yang berorientasi pada kualitas ini menghadapi berbagai tantangan yang tidak bisa ditanggulangi dengan paradigma yang lama. Ilmu pengetahuan dan teknologi yang berkembang cepat tidak dapat dikejar dengan caracara lama yang dipakai dalam sekolah-sekolah kita. ${ }^{3}$

Teori merupakan hal yang sangat peting dalam kemajuan dunia, baik di dunia militer maupun di dunia pendidikan. Dalam hal pendidikan teori menempati sangat strategis, sebab dengan mengembangkan teori maka pengetahuan dan pengalaman semakin berkembang. Berbicara tentang teori, dalam dunia pendidikan banyak sekali teori-teori yang cocok untuk mengembangkan dunia pendidikan, salah satunya yaitu teori konstruktivisme.

${ }^{1}$ Conny Semiawan, dkk, Pendekatan Keterampilan Proses, (Jakarta, PT Gramedia: 1990). Hal.1

2 Zamroni, Pendidikan dan Demokrasi dalam Transisi (Prakondisi Menuju Era Globalisasi), (Jakarta, PSAP Muhammadiah : 2007), hal.237-238.

${ }^{3}$ W. Gulo, Strategi Belajar-Mengajar (Jakarta, PT Grasindo: 2002). Hal..vii 


\section{TEORI}

Secara umum teori merupakan sejumlah proposal yang terintegrasi secara sintakstik (kumpulan proposisi ini mengikuti aturan-aturan yang dapat menghubungkan secara logis proposal yang satu dengan proposal yang lain, dan juga pada data yang diamati), serta yang digunakan untuk memprediksi dan menjelaskan peristiwa-peristiwa yang diamati. ${ }^{4}$ Berdasarkan penjelasan tersebut maka dapat dijelaskan bahwa terori merupakan kumpulan-kumpulan pemikiran seseorang yang sesuai dengan aturan-aturan yang berlaku dan dapat diterima oleh akal sehat semua orang.

\section{FUNGSI TEORI}

Snelbecker mengatakan bahwa perumusan teori itu bukan hanya penting, melainkan juga vital bagi psikologi dan pendidikan agar dapat maju atau berkembang, serta memecahkan masalah-masalah yang ditemukan dalam setiap bidang itu. ${ }^{5}$ Berdasarkan pendapat tersebut maka dapat di ketahui bahwa teori dalam pendidikan mempunyai peran atau fungsi yang yang sangat strategis, sebab dengan terori tersebut maka pendidikan akan menjadi berkembang. Sebaliknya bila dalam pendidikan tidak mempunyai teori maka dapat di pastikan tidak akan berkembang sesuai dengan yang diharapkan.

Selanjutnya menurut Snelbecker bahwa teori dalam pendidikan memiliki peran untuk memecahkan setiap daripada permasalahan-permasalahan yang dihadapi. Bila kita melihat bahwa permasalahan sangat banyak sekali dalam dunia pendidikan atau bahkan juga di luar. Maka untuk menyelesaikan setiap permasalahan tersebut maka dibutuhkanlah sebuah teori-teori yang mampu memberikan jalan keluar dari hal tersebut. Bila dilihat maka jelaslah bahwa sebuah teori mempunyai fungsi yang sangat strategis dalam memajukan pendidikan.

Untuk lebih jelasnya di lihat beberapa fungsi dari pada sebuah teori, diantaranya yaitu : pertama memberikan penemuan-penemuan menjadi sistematis. Maksudnya yaitu setiap penelitian membutuhkan ketelitian dan kehati-hatian dalam setiap apa yang di teliti tersebut, apa lagi setiap penelitian tersebut masih bersifat

${ }^{4}$ Ibid. hal...12

${ }^{5}$ Ratna Wilis Dahar, Teori-Teori Belajar \& Pembelajaran, (Jakarta: Erlangga. 2006). Hal.10 
ragu-ragu atau masih samar-samar, untuk membuktikan hasil dari setiap penelitiannya tersebut maka dibutuhkanlah sebuah teori, dengan harapan untuk memperjelas atau memperkuat dari pada hasil penelitiannya sebelum di publikasikan.

Kedua melahirkan hipotesis, maksudnya setiap penelitian membutuhkan hipotesis, sebab tanpa sebuah hipotesis maka penelitiannya itu kurang baik, sebab hipotesis mempunyai fungsi tersendiri dalam setiap penelitian. sebelum seseorang peneliti melakukan sebuah penelitian maka apa yang menjadi rancangannya tersebut perlu pembuktian-pembuktian dengan menggunakan sebuah hipotesis-hipotesis.

ketiga membuat prediksi, maksudnya yaitu sebuah terori harus bisa melahirkan sebuah prediksi-prediksi sementara dari pada anggapan-anggapan kita sebagai peneliti, untuk membuktikannya tersebut maka dibutuhkanlah sebuah teori untuk memberikan atau membuktikannya apakah benar tidak atau sesuai dengan pemikiran peneliti, dan yang terakhir memberi penjelasan. ${ }^{6}$ Maksudnya yaitu memberikan bukti-bukti yang kuat serta penjelasan-penjelasan yang akurat sesuai dengan prosedur-prosedur yang berlaku dalam setiap penelitian.

\section{Teori Konstruktivisme}

Teori konstruktivisme merupakan teori yang sudah tidak asing lagi bagi dunia pendidikan, sebelum mengetahui lebih jauh tentang teori konstruktivisme alangkah lebih baiknya di ketahui dulu konetruktivisme itu sendiri. Konstruktivisme berarti bersifat membangun. Dalam konteks filsafat pendidikan, konstruktivisme adalah suatu upaya membangun tata susunan hidup yang berbudaya modern. ${ }^{7}$ Berdasarkan penjelasan tersebut di atas, bahwa konstruktivisme merupakan sebuah teori yang sifatnya membangun, membangun dari segi kemampuan, pemahaman, dalam proses pembelajaran. Sebab dengan memiliki sifat membangun maka dapat diharapkan keaktifan dari pada siswa akan meningkat kecerdasannya.

Merasa kurang lengkap untuk mengetahui dari pada teori konstruktivisme sebelum mengetahui pendapat-pendapat dari pada pakar ahli, diantaranya yaitu : Hill, mengatakan, sebagai pembelajaran yang bersifat generatif, yaitu tindakan mencipta

\footnotetext{
${ }^{6}$ Ibid, hal..10-12

7 Agus N Cahyo, Panduan Aplikasi Teori-Teori Belajar Mengajar Teraktual Dan Terpopuler, (Jogjakarta, Divapres: 2013). Hal.33
} 
sesuatu makna dari apa yang di pelajari. ${ }^{8}$ Menurut hill konstruktivisme merupakan bagaimana menghasilkan sesuatu dari apa yang dipelajarinya, dengan kata lain bahwa bagaimana memadukan sebuah pembelajaran dengan melakukan atau mempraktikkan dalam kehidupannya supaya berguna untuk kemaslahatan.

Shymansky mengatakan konstuktivisme adalah aktivitas yang aktif, di mana peserta didik membina sendiri pengetahuannya, mencari arti dari apa yang mereka pelajari, dan merupakan proses menyelesaikan konsep dan ide-ide baru dengan kerangka berfikir yang telah ada dimilikinya. ${ }^{9}$ Berdasarkan pendapatnya di atas, maka dapat di pahami bahwa konsturktivisme merupakan bagaimana mengaktifkan siswa dengan cara memberikan ruang yang seluas-luasnya untuk memahami apa yang mereka telah pelajari dengan cara menerpakan konsep-konsep yang di ketahuinya kemudian mempaktikkannya ke dalam kehidupan sehari-harinya. Berdasarkan pendapat para ahli di atas, maka dapat dibuat sebuah kesimpulan yaitu konstruktivisme merupakan sebuah teori yang memberikan keluasan berfikir kepada siswa dan memberikan siswa di tuntut untuk bagaimana mempraktikkan teori yang sudah di ketahuinya dalam kehidupannya.

\section{Asumsi-Asumsi Konstruktivisme}

Kosntruksivisme menyoroti interaksi orang-orang dan situasi-situasi dalam penguasaan dan penyempurnaan keterampilan-keterampilan dan pengetahuan. Konstuktivisme memiliki asumsi yang sama dengan teori kognitif sosial yang mengarahkan bahwa orang, prilaku, dan lingkungan berinteraksi secara timbal balik. Adapun asumsi-asumsi dari konstruktivisme adalah, pertama, manusia merupakan siswa aktif yang mengembangkan pengetahuan bagi diri mereka sendiri. ${ }^{10}$ Di mana siswa diberikan keluasan untuk mengembangkan ilmu yang sudah didapatkan tersebut, baik dengan melakukan latihan, melakukan eksperimen maupun berdiskusi sesama siswa. Dengan hal seperti itu maka ilmu-ilmunya tersebut akan berkembang dan bertambah.

\footnotetext{
${ }^{8}$ Ibid, hal..34

${ }^{9}$ Ibid..hal 35-36

${ }^{10}$ Dale H. Schunk, Learning Theories An Education Perspective, Di Terjemabkan Oleh Eva Hamdiah, Rahmat Fajar, Dengan Judul Teori-Teori Pembelajaran Perspektif Pendidikan. (Yogyakarta, Pustaka Pelajar: 2012). Hal.323
} 
Kedua. Guru sebaiknya tidak mengajar dalam artian menyampaikan pelajaran dengan cara tradisional kepada sejumlah siswa. Guru seharusnya membangun situasisituasi sedemikian rupa sehingga siswa dapat terlibat secara aktif dengan materi pelajaran melalui pengolahan materi-materi dan interaksi sosial. ${ }^{11}$ Maksudnya seorang pendidik atau guru dituntut untuk lebih aktif dan menarik dalam menjelaskan, selain itu juga guru harus bisa menggunakan media dalam proses pembelajaran. Jangan hanya menggunakan metode-metode yang sudah lama atau jaman dulu, seperti ceramah, mencatat sampai habis, akan tetapi guru harus mengajar dengan cara bagaimana supaya siswa harus di buat aktif dan masuk dalam pembelajaran tersebut.

Adapun aktivitas-aktivitas pembelajaran meliputi mengamati fenomenafenomena, mengumpulkan data-data, merumuskan dan menguji hipotesis-hipotesis, dan bekerja sama dengan orang lain. Kegiatan lainnya adalah mengajak siswa mengunjungi lokasi-lokasi di luar ruangan kelas. Guru-guru dari berbagai disiplin ilmu diperlukan untuk merencanakan kurikulum bersama-sama. Siswa perlu diarahkan untuk dapat mengatur diri sendiri dan berperan aktif dalam pembelajaran mereka dengan menentukan tujuan-tujuan, memantau dan mengevaluasi kemajuan mereka, dan bertindak melampaui standar-standar yang disyaratkan bagi mereka dengan menelusuri hal-hal yang menjadi minat mereka. ${ }^{12}$

\section{Perspektif-Perspektif Dalam Konstruktivisme}

Pertama, konstruktivisme eksogeneus mengacu pada pemikiran bahwa penguasaan pengetahuan merepresentasikan sebuah kosntruksi ulang dari strukturstruktur yang berbeda dalam dunia eksternal. Pandangan ini mendasarkan pengaruh kuat dari dunia luar pada konstruksi pengetahuan, seperti pengalaman-pengalaman, pengajaran dan pengamatan terhadap model-model.

Kedua, konstruktivisme endogenus menekankan pada koordinasi tindakantindakan yang sebelumnya, bukan secara langsung dari informasi lingkungan; karena itu, pengetahuan bukanlah cerminan dari dunia luar yang diperoleh melalui pengalaman-pengalaman, pengajaran, atau interaksi sosial. Pengetahuan berkembang

11 Ibid..hal.324

12 Ibid.hal..324 
melalui aktifitas kognitif dari abstraksi dan mengikuti sebuah rangkaian yang dapat diprediksikan secara umum.

Ketiga, konstruktivisme dialektikal. berpendapat bahwa pengetahuan tidak hanya dapat diperoleh melalui sekolah akan tetapi bisa juga di dapatkan melalui saling berinteraksi sesama teman, guru, tetangga dan bahkan lingkungan sekitar kita. Selain itu juga interpretasinya tidak terikat dengan dunia luar. Bahkan pengetahuan atau pemahaman timbul akibat saling berlawanan mental dari interaksi antara lingkungan sekitar dengan seseorang. ${ }^{13}$

Dari ketiga pandang tersebut memiliki kelebihan masing-masing, seperti konstruktivisme eksogeneus yaitu untuk mengetahui sejauh mana pengetahuan seorang siswa terhadap ilmu tertentu secara akurat dan terperinci. Kemudian konstruktivisme endogenus yaitu untuk mengetahui sejauh mana penguasaan materi secara terstruktur mulai dari yang paling bawah sampai dengan yang paling tinggi. Sedangkan konstruktivisme dialektikal digunakan ketika guru atau pendidik ingin merencanakan itervensi-intervensi untuk mendorong pemikiran siswa dan untuk mengarahkan penelitian untuk menemukan efektifitas dari pengaruh-pengaruh sosial seperti paparan terhadap model-model dan kerja sama dengan teman sebaya.

\section{Kelebihan Konstruktivisme}

Hidup ini, tidak ada yang sempurna ada kebaikan ada juga keburukan, begitu juga dengan sebuah teori. Tidak ada teori yang sempurna akan tetapi saling melengkapi antara yang satu dengan yang lainya begitu juga konstruktivisme. Adapun kelebihan dari teori konstruktivisme diantaranya :

Pertama, guru bukan satu-satunya sumber belajar. ${ }^{14}$ Maksudnya yaitu dalam proses pembelajaran guru hanya sebagai pemberi ilmu dalam pembelajaran, siswa tuntut untuk lebih aktif dalam proses pembelajarannya, baik dari segi latihan, bertanya, praktik dan lain sebagainya, jadi guru hanya sebagi pemberi arah dalam pembelajaran dan menyediakan apa-apa saja yang dibutuhkan oleh siswanya. Sebab dalam kosntruktivisme pengetahuan itu tidak hanya di dapatkan dalam proses

13 Ibid,..hal..235-236

${ }^{14}$ Agus N cahyo,.hal..69 
pembelajaran akan tetapi bisa juga di dapatkan melalui diskusi, pengalaman dan juga bisa di dapatkan di lingkungan sekitarnya.

Kedua, siswa (pembelajaran) lebih aktif dan kreatif. ${ }^{15}$ Maksudnya di mana siswa dituntut untuk bisa memahami pembelajarannya baik di dapatkan di sekolah dan yang dia dapatkan di luar sekolah, sehingga pengetahuan-pengetahuannya yang dia dapatkan tersebut bisa dia kaitkan dengan baik dan seksama, selain itu juga siswa di tuntut untuk bisa memahami ilmu-ilmu yang baru dan dapat di koneksikan dengan ilmu-ilmu yang sudah lama.

Ketiga, pembelajaran menjadi lebih bermakna. Belajar bermakna berarti menginstrksi informasi dalam struktur penelitian lainnya. ${ }^{16}$ Artinya pembelajaran tidak hanya mendengarkan dari guru saja akan tetapi siswa harus bisa mengaitkan dengan pengalaman-pengalaman pribadinya dengan informasi-informasi yang dia dapatkan baik dari temanya, tetangganya, keluarga, surat kabar, televisi, dan lain sebagainya.

Keempat, pembelajaran memiliki kebebasan dalam belajar. Maksudnya siswa bebas mengaitkan ilmu-ilmu yang dia dapatkan baik di lingkungannya dengan yang di sekolah sehingga tercipta konsep yang diharapkannya. Kelima, perbedaan individual terukur dan di hargai. Keenam, guru berfikir proses membina pengetahuan baru, siswa berfikir untuk menyelesaikan masalah, dan membuat keputusan. ${ }^{17}$

\section{Kekurangan Konstruktivisme}

Pertama, proses belajar konstruktivisme secara konseptual adalah proses belajar yang bukan merupakan perolehan informasi yang berlangsung satu arah dari luar ke dalam diri siswa kepada pengalamannya melalui proses asimilasi dan akomodasi yang bermuara pada pemutakhiran sruktur kognitif. Kedua, peran siswa. Menurut pandangan ini, belajar merupakan suatu proses pembentukan pengetahuan. Ketiga, peran guru. Dalam pendekatan ini guru atau pendidik berperan membantu agar proses pengonstruksian pengetahuan oleh siswa berjalan lancar. Guru tidak

\footnotetext{
15 Ibid, hal..69

${ }^{16}$ Ibid, hal..69

${ }^{17}$ Ibid, hal.. 70
} 
menerapkan pengetahuan yang telah dimilikinya, melainkan membantu siswa untuk membentuk pengetahuannya sendiri. ${ }^{18}$

Keempat, sarana belajar. Pendekatan ini menekankan bahwa peran utama dalam kegiatan belajar adalah aktifitas siswa dalam mengonstruksi pengetahuannya sendiri. Kelima, evaluasi, pandangan ini mengemukakan bahwa lingkungan belajar sangat mendukung munculnya berbagai pandangan dan interpretasi terhadap realitas, konstruksi pengetahuan, serta aktifitas-aktifitas lain yang didasarkan pada pengalaman. ${ }^{19}$

\section{KESIMPULAN}

Fungsi dari pada sebuah teori, diantaranya yaitu : pertama memberikan penemuan-penemuan menjadi sistematis. Kedua melahirkan hipotesis, maksudnya setiap penelitian membutuhkan hipotesis, sebab tanpa sebuah hipotesis maka penelitiannya itu kurang baik, sebab hipotesis mempunyai fungsi tersendiri dalam setiap penelitian. ketiga membuat prediksi, maksudnya yaitu sebuah terori harus bisa melahirkan sebuah prediksi-prediksi sementara dari pada anggapan-anggapan kita sebagai peneliti, untuk membuktikannya tersebut maka dibutuhkanlah sebuah teori untuk memberikan atau membuktikannya apakah benar tidak atau sesuai dengan pemikiran peneliti, dan yang terakhir memberi penjelasan.

Teori konstruktivisme merupakan teori yang sudah tidak asing lagi bagi dunia pendidikan, sebelum mengetahui lebih jauh tentang teori konstruktivisme alangkah lebih baiknya di ketahui dulu konetruktivisme itu sendiri. Konstruktivisme berarti bersifat membangun. Dalam konteks filsafat pendidikan, konstruktivisme adalah suatu upaya membangun tata susunan hidup yang berbudaya modern.

${ }^{18} \mathrm{Ibid}, .$. hal..70-71

${ }^{19} \mathrm{Ibid}$, hal..72-73 
Suparlan

\section{DAFTAR PUSTAKA}

Agus N Cahyo, Panduan Aplikasi Teori-Teori Belajar Mengajar Teraktual Dan Terpopuler, ,Jogjakarta, Divapres: 2013.

Conny Semiawan, dkk, Pendekatan Keterampilan Proses, Jakarta, PT Gramedia: 1990.

Dale H. Schunk, Learning Theories An Education Perspective, Di Terjemabkan Oleh Eva Hamdiah, Rabmat Fajar, Dengan Judul Teori-Teori Pembelajaran Perspektif Pendidikan. ,Yogyakarta, Pustaka Pelajar: 2012.

Ratna Wilis Dahar, Teori-Teori Belajar \& Pembelajaran, Jakarta: Erlangga. 2006.

W. Gulo, Strategi Belajar-Mengajar, Jakarta, PT Grasindo: 2002.

Zamroni, Pendidikan dan Demokrasi dalam Transisi (Prakondisi Menuju Era Globalisasi), Jakarta, PSAP Muhammadiah : 2007. 